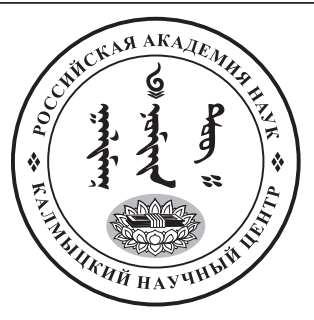

Published in the Russian Federation

Oriental Studies (Previous Name: Bulletin of the Kalmyk Institute

for Humanities of the Russian Academy of Sciences)

Has been issued as a journal since 2008

ISSN: 2619-0990; E-ISSN: 2619-1008

Vol. 13, Is. 2, pp. 305-317, 2020

DOI: $10.22162 / 2619-0990-2020-48-2-305-317$

Journal homepage: https://kigiran.elpub.ru

УДК 94 (517)

\title{
Отто Иванович Макстенек: \\ у истоков монгольской революции 1921 года
}

Хииигт Норовсамбуу ${ }^{1}$

Леонид Владимирович Курас ${ }^{2}$

Базар Догсонович Цыбенов ${ }^{3}$

${ }^{1}$ Институт истории и этнологии Монгольской академии наук (район Баянзурх, 13-й микрорайон, пр. Мира, 13330 Улан-Батор, Монголия)

$\mathrm{Ph} . \mathrm{D}$, профессор, врио директора

(D) 0000-0003-3608-4966. E-mail: khishigt_58@yahoo.com

${ }^{2}$ Институт монголоведения, буддологии и тибетологии СО РАН

(д. 6, ул. Сахьяновой, 670047 Улан-Удэ, Российская Федерация)

доктор исторических наук, профессор, главный научный сотрудник

(iD) 0000-0003-4507-249X. E-mail: kuraslv@yandex.ru

${ }^{3}$ Институт монголоведения, буддологии и тибетологии СО РАН

(д. 6, ул. Сахьяновой, 670047 Улан-Удэ, Российская Федерация)

кандидат исторических наук, старший научный сотрудник

iD 0000-0002-0404-7207.E-mail: bazar75@mail.ru

Аннотация. Введение. Монгольская революция 1921 г. представляет собой результат активного двустороннего взаимодействия монгольских и советских революционеров. В подготовке революции, в частности в советско-монгольских переговорах 1920-1921 гг. и препровождении монгольских делегатов из пограничного Троицкосавска в ДВР и Советскую Россию в 1920 г., большую роль сыграл уполномоченный НКИД РСФСР в Монголии О. И. Макстенек. Цели $u$ задачи исследования. Статья посвящена изучению деятельности О. И. Макстенека на должности уполномоченного НКИД РСФСР в Монголии с июня 1920 по март 1921 гг. Для ее решения ставятся следующие задачи: 1) освещение политической ситуации в Монголии и сопредельных регионах - Дальнем Востоке и Забайкалье (по данным О. И. Макстенека); 2) ввод в научный оборот архивных сведений об информационной, организационной, дипломатической, политической и экономической деятельности О. И. Макстенека. Материалами исследования являются документы из Архива МИД Монголии под названием «Итоги деятельности уполномоченного Наркоминдел в Монголии О. И. Макстенек за время с 1-го июня 1920 г. по март 1921 г.». Результаты. Получены неизвестные ранее, ценные сведения о разносторонней активной деятельности О. И. Макстенека. В частности, выяснены детали и особенности встреч Макстене- 
ка и членов МНРП в Троицкосавске в 1920 г.; вопрос о занятии Маймачена, рассмотренный в феврале 1921 г., имена деятелей изучаемого периода. Bыводы. Уполномоченный НКИД в Монголии О. И. Макстенек, вынужденно находясь в Троицкосавске в июне 1920 - марте 1921 гг., провел большую работу в деле подготовки Монгольской революции 1921 г. Благодаря ему монгольские делегаты смогли беспрепятственно продвигаться из Троицкосавска в другие города ДВР и Советской России, а также организовывать в Троицкосавске собрания МНРП.

Ключевые слова: Монгольская революция, О.И. Макстенек, Троицкосавск, Урга, НКИД РСФСР, Коминтерн

Благодарность. Исследование проведено в рамках проекта РФФИ - Министерства образования, культуры и науки (Монголия), № 19-59-44004 «Монгольская революция 1921 г. в зеркале транснациональной истории монгольского мира» (к 100-летию Монгольской революции 1921 г.) (номер госрегистрации АААА-А20-120021490062-5).

Для цитирования: Хишигт Н., Курас Л. В., Цыбенов Б. Д. Отто Иванович Макстенек: у истоков монгольской революции 1921 года // Oriental studies. 2020. Т. 13. № 2 C. 305-317. DOI: 10.22162/2619-0990-2020-48-2-305-317

UDC 94 (517)

\title{
Otto I. Makstenek: at the Origins of the Mongolian Revolution of 1921
}

\author{
Khishigt Norovsambuu ${ }^{1}$ \\ Leonid V. Kuras ${ }^{2}$ \\ Bazar D. Tsybenov ${ }^{3}$
}

${ }^{1}$ Institute of History and Ethnology, Mongolian Academy of sciences

(Bayanzürkh District, Microdistrict 13, Enkh Taivny Ave., Ulaanbaatar 13330, Mongolia)

Ph. D, Professor, Deputy Director

iD 0000-0003-3608-4966. E-mail: khishigt_58@yahoo.com

${ }^{2}$ Institute for Mongolian, Buddhist and Tibetan Studies, Siberian Branch of the RAS

(6, Sakhyanova St., Ulan-Ude 670047, Russian Federation)

Dr. Sc. (History), Professor, Chief Research Associate

iD 0000-0003-4507-249X. E-mail: kuraslv@yandex.ru

${ }^{3}$ Institute for Mongolian, Buddhist and Tibetan Studies, Siberian Branch of the RAS

(6, Sakhyanova St., Ulan-Ude 670047, Russian Federation)

Cand. Sc. (History), Senior Research Associate

iD 0000-0002-0404-7207. E-mail: bazar75@mail.ru

\begin{abstract}
Introduction. The Mongolian Revolution of 1921 was the result of active bilateral interaction between Mongolian and Soviet revolutionaries. It was the authorized representative of the People's Commissariat for Foreign Affairs of the RSFSR to Mongolia O. I. Makstenek who contributed a lot to the preparation of the Mongolian Revolution of 1921: he participated in the SovietMongolian negotiations of 1920-1921, and met Mongolian delegates who arrived at the border point of Troitskosavsk from Outer Mongolia. Goals and Objectives. The article studies O. I. Makstenek's activities when a Soviet Russia's plenipotentiary representative to Mongolia from June 1920 to March 1921. To facilitate this, the work 1) examines the then political situation in Mongolia and adjacent territories - the Russian Far East and Baikalia (as reported by O. I. Makstenek), 2) introduces into scientific discourse some archival materials dealing with his informational, organizational, diplomatic, political, and economic efforts. Materials. The study investigates documents stored by the Archives of Mongolia's Ministry of Foreign Affairs titled 'O. I. Makstenek, Authorized Officer of the People's Commissariat for Foreign Affairs in Mongolia, and Results of His Work: 1 June 1920 to March 1921'.
\end{abstract}


Results. The study reveals previously unknown and valuable facts about diverse and productive activities of O. I. Makstenek. It casts light on details and peculiarities of his 1920 Troitskosavsk-based meetings with MPRP (Mongolian People's Revolutionary Party) members, February 1921 debates on the occupation of Maimaicheng; identifies names of involved Soviet, Mongolian and Chinese leaders, White Guard commanders. Conclusions. The authorized representative of the People's Commissariat for Foreign Affairs of the RSFSR to Mongolia O. I. Makstenek could not leave for Urga staying in Troitskosavsk between June 1920 and March 1921 but did a great job in preparing the Mongolian revolution of 1921. It was through his efforts that the Mongolian delegates without any restrictions were travelling via Troitskosavsk to other cities of the Far Eastern Republic and Soviet Russia, and would organize meetings of the MPRP in Troitskosavsk.

Keywords: Mongolian revolution, O. I. Makstenek, Troitskosavsk, Urga, People's Commissariat for Foreign Affairs of the RSFSR, Comintern

Acknowledgements: The reported study was funded by RFBR and Ministry of Education, Culture and Science of Mongolia, no. 19-59-44004 'The Mongolian Revolution of 1921 in the Mirror of Transnational History of the Mongolian World: Celebrating the $100^{\text {th }}$ Anniversary of the Mongolian Revolution of 1921' (state reg. no. AAAA-A20-120021490062-5).

For citation: Khishigt N., Kuras L. V., Tsybenov B. D. Otto I. Makstenek: at the Origins of the Mongolian Revolution of 1921. Oriental Studies. 2020; Vol. 13(2): 305-317 (In Russ.). DOI: 10.22162/2619-0990-305-317.

\section{है}

\section{Введение}

В 1921 г. исполняется 100 лет Монгольской революции, которая была обусловлена всем ходом исторического развития страны. Она явилась закономерным результатом длительной борьбы монгольского народа за национальное и социальное освобождение. В то же время Монгольская революция - это проблема революционизации всего монгольского мира в первой четверти $\mathrm{XX}$ в. И потому событие вековой давности, несомненно, выходит за рамки локального процесса, а значит, его следует рассматривать в русле транснациональной истории монгольского мира [Курас 2016б]. Именно поэтому у истоков революции стояли не только монгольские революционеры и, прежде всего, знаменитая монгольская семерка: С. Данзан, Х. Чойбалсан, Д. Бодоо, Д. Чагдаржав, Д. Сухэ-Батор, Д. Догсом и Д. Лосол, вклад которых в революцию и национально-государственное строительство Монголии получил достойное освещение в монгольской историографии [Хишигт 2011]. Деятельность российских партийных функционеров, коминтерновцев, дипломатов и бурятских национальных демократов, сыгравших большую роль в Монгольской революции, также получила высокую оценку в научной исторической литературе. При этом особенно выделяется организационная и практическая деятельность Б. 3. Шумяцкого и Э.-Д. Ринчино [Жабаева 2001; Курас 2016а; Курас 2017]. Однако вне поля зрения оказалась жизнь и деятельность советского дипломата, первого уполномоченного Народного комиссариата иностранных дел (далее - НКИД) РСФСР в Монголии Отто Ивановича Макстенека, внесшего существенный вклад в осуществление Монгольской революции 1921 г., что было отмечено высокой правительственной наградой Монголии - Орденом Красного Знамени МНР [ГА РФ. Ф. 10035. Оп. 1. Д. П-61825. Л. 5]. Статья посвящена изучению деятельности О. И. Макстенека на должности уполномоченного НКИД РСФСР в Монголии с июня 1920 по март 1921 гг. Для ее решения ставятся следующие задачи: 1) освещение политической ситуации в Монголии и сопредельных регионах - Дальнем Востоке и Забайкалье (по данным О. И. Макстенека); 2) ввод в научный оборот архивных сведений об информационной, организационной, дипломатической, политической и экономической деятельности О. И. Макстенека. 


\section{Основная часть}

В июне 1920 г. в пограничном городе Троицкосавске начало работать представительство НКИД Советской России в Монголии. Уполномоченным НКИД РСФСР в Монголии был назначен О. И. Макстенек. Однако он не был пропущен китайскими оккупационными властями в Ургу и был вынужден остановиться на границе, в Троицкосавске. Обосновавшись здесь, дипломат приступил к налаживанию контактов с монгольскими революционерами и организации их связи с представителями Советской власти и Коминтерна в Сибири.

Современная российская историография имеет в своем активе лишь разрозненные документы о жизни и деятельности О. И. Макстенека. Среди них:

1) «Мартиролог жертв политических репрессий, расстрелянных и захороненных в Москве и Московской области в 1918 1953 гг.», где ни единым словом не упомянута работа О. И. Макстенека на посту дипломата [Мартиролог];

2) дело по обвинению Макстенека Отто Ивановича по ст. 58-10-11 УК РСФСР, находящееся на хранении в Государственном архиве Российской Федерации [ГА РФ. Ф. 10035. Оп. 1. Д. П-61825. 50 л.];

3) двухтомный сборник документов, посвященный российско-монгольскому военному сотрудничеству в 1911-1946 гг., где опубликована оперативная информация за подписью О. И. Макстенека в адрес ответственных работников НКИД РСФСР и Восточного отдела Коминтерна по монгольскому вопросу [Российско-монгольское... 2019а; Российско-монгольское... 2019б];

4) воспоминания видного советского дипломата-китаиста М. И. Казанина с описанием внешности О. И. Макстенека [Казанин 2009];

5) описание внешности российского дипломата мы также находим в работе одного из архитекторов Монгольской революции, видного государственного деятеля и военачальника Х. Чойбалсана [Чойбалсан, Лосол, Демид 1979: 12].

На сегодня российская историография располагает пока единственной публикацией авторов настоящей статьи, посвященной непосредственно дипломатической деятельности О. И. Макстенека на посту Уполномоченного НКИД РСФСР в Монголии [Курас, Цыбенов 2020].
Bсе это подвело нас к мысли о необходимости опубликования в полном объеме уникального документа «Итоги деятельности уполномоченного Наркоминдел в Монголии О. И. Макстенек за время с 1-го июня 1920 г. по март 1921 г.», подготовленного лично Отто Ивановичем. Документ дает полное представление обо всем объеме работы по информационному обеспечению директивных органов Советской России о положении в Китае и Монголии, организационной, дипломатической, политической и экономической работе, которую советский дипломат осуществлял в течение 10 месяцев на посту Уполномоченного.

Заверенная копия отчета О. И. Макстенека находится на хранении в архиве Министерства иностранных дел Монголии [Архив МИД Монголии. Ф. 495. Оп. 152. Д. 9. Л. 45-57].

Документ «Отчет О. И. Макстенека с 1 июня 1920 г. по март 1921 г. ${ }^{1}$ »

Введение. Революичонное движение, захватившее виирь и вглубь всю Россию, неминуемо долюно было отвлечь ее внимание от ее окраин, чем, конечно, воспользовались ее соседи с капиталистическими правительствами. Давно уже Китай соперничает с Россией за первенство влияния в Монголии и неуклонно следили соперниць друг за другом, пользуясь всяким случаем, чтобы укрепить свой авторитет в этой обширной и богатой сырьем стране. И, конечно, не с радостью встретил Китай инсиенированную русскую деклараичю об автономии Монголии, ибо Китаю было хорошо известны те автономии, каковые исходят от ияарей и королей. Китай понимал, что за автономией кроется внедрение русского экономического влияния в Монголии и, следовательно, вытеснение китайского. Китай занял выжидательное положение. И ждать пришлось недолго. Коренная ломка русского государственного строя, внешняя и внутренняя война не давали возможности заботиться об окраинах и предоставляли полную свободу действий всем тем, кто пожелал бы воспользоваться временной слабостью России. Китаю не трудно было покончить с той не большой автономией,

1 Документ приводится в соответствии с источником: орфография и пунктуация сохранены. Дополнения авторов статьи к тексту документа указываются в квадратных скобках. 
каковая была введена в Монголии Россией, и также не трудно было Китаю при посредстве грубой силь покончить со всеми русскими экономическими завоеваниями в Монголии в сравнительно в короткий срок.

Между тем в настоящее время экономическое положение на Дальнем Востоке создалось именно таковым, что Монголия должна быть включена в цеепь хозяйственной жизни всей этой обширной окраины и, следовательно, выпадение какого-либо звена неуклонно поведет к расстройству всего экономического аппарата данной области. Выввод ясен и только один - без Монголии, без ее сырья и ее рынка Дальний Восток обречен на жалкое существование. Таково было общее понимание Монгольского вопроса, когда по предложению Сибмиссии я отправился в иеентр административной и экономической жизни Монголии - Ургу, в начале июня прошлого года в качестве Уполномоченного Наркоминдел. Время моего приезда к границе Монголии в Троицкосавске совпало с полным засильем японцев в Пекинском Правительстве и нет ничего удивительного, если так категорически отказали мне в пропуске в Монголию для зашчиты интересов России, там китайские правители под руководством японцев выполняли те поручения Антанты, сводяшуиеся к осущуествлению полной блокады коммунистов. Пришлось таким образом остаться в Троицкосавске и выжидать более благоприятного времени. Телеграфным распоряжением Сибмиссии мне было предложено установить связь с Монголией и дабы представилась возможность, хотя бы в части осуществлять поставленные задания и иели. Кроме того, на меня была возложена работа Регистротдела, какой в последствии пришлось уделять значительное внимание, а также согласно мандата Иргубпродкомиссара наблюдение и контроль Центросоюза.

Как везде в России, так и здесь вдали на окраине ошущуается острый недостаток в людях. Чуть ли не с первых же дней своей работы в Троицкосавске определилось, что мне сейчас же надо взять на себя контроль над Центросоюзом, являвшимся в то время мошцылм орудием контрреволюиии. Конечно, здесь не понимается организация Центросоюза в полном смысле этого слова, но многие ответственные работники в Троиц- косавске, а особенно в Урге занимались всяческой поддержкой белогвардейских банд. Центросоюз, имея в своем распоряжении огромные народные финансовые средства, являлся приютом для черной сотни работавшей в то время в Монголии, а при более близком знакомстве, Ургинский и Ванкуренский пункты Центросоюза в изелом не только содействовали контрреволючуии, но и фактически являлись их главной базой. Необходимо было поставить всей этой вакханалии предел, вместе с тем также необходимо было сохранить эту организацию являвшейся жизненно важной для устранения продовольственного кризиса, иарившего в то время в Забайкалье. Не менее важным являлось в то время не прерывать снабжение мясом нашей армии, - каковое снабжение было поручено Центросоюзу.

Таким образом, деятельность моя в Троицкосавске была разносторонней и по своей сущнности распадается на несколько категорий:

1) информацчионая; 2) организационная; 3) дипломатическая; 4) политическая; 5) экономическая.

Работа по информаччии: Первыми шагами по этой работе было создать связь с главнейшими пунктами Китая. Ввиду отсутствия в то время какого-либо сообщения через Маньчжурию с Китаем, единственным путем являлся монгольский путь, - через Ургу. Представлялось необходимым завязать тесное отношение с Ургинским информацчионным бюро, каковое впоследствии наладилось во всех отношениях. Удалось в сравнительно короткий срок наладить доставку всех важнейших газет Китая, Японии и других как на английском, франиузском и туземном языках. Здесь в Троицкосавске было организована систематическая сводка всех важнейших сведений и перевод руководящих статей из газет и немедленная телеграфная передача всех газетных материалов как в Сибмиссию, так и Наркоминделу. Вся информация печаталась мной лично на тонкой бумаге в 6-8 экземплярах и препровождалась в следуюшие адреса: 1) Наркоминдел Москва; 2) Сибмиссия Иркутск; 3) Предсибревком Омск; 4) Дальнев. В-Удинск; 5) Регистротдел Иркутск; 6) Местный партком и др.

Все сведения военного и стратегического характера о китайских войсках, их пере- 
движений и вооружения, а также сведения о белогвардейских организациях и вообще о контрреволючионерах препровождались в Регистротдел в Иркутске. Но кроме всего этого представительство Советской России в Троицкосавске являлось центром концентрации всей вообще информации, частной и государственной. Здесь же черпали свою информацию все правительственные и общественные учреждения. Так, например, Госполитохрана обменивалась своей информачией с нами, точно так же систематически получали от меня информацию Начпогранрайона, Партком и др.

Следует также отметить, что по части информации мне приходилось исполнять и технические работы, как-то: переснимка карт данного района, рисунки кит. военных флагов, точно также приходилось изготавливать военные карты для Регистротдела о расположении китвойск, буферных и дор. Далее вся получаемая мной литература на монгольском и китайском языках при первых оказиях препровождалась в соответствуюшие районы, причем не упускалось ни одного случая, чтобы не снабдить наших сотрудников указанной литературой для распространения.

ОРГАНИЗАЦИОННАЯ РАБОТА: Организационная работа началась с знакомства c отдельными членами Нарревпартии. Приблизительно в середине июня прошлого года начали прибывать ко мне члены НРП. В частности, первое мое знакомство относится к товарищам Данзану и Чойбалсану, каковые прибыли ко мне из Урги от товарищза Кучеренко, который теперь Унгерном убит в Урге. Затем почти все работники, имеюшие отношение к работе в Монголии, проходили через меня. На меня легла обязанность снабжения всех приезжавиих работников документами, обмен тех изенностей, которые они привозили с собой на китайские янчены, подыскание конспиративных квартир и т. д. Вся эта работа должна была проходить с соблюдением величайшей осторожности, так как китайцыы неустанно следили за всей моей работой, точно также они зорко следили за всеми членами НРП. Приходилось входить в тесный контакт с местныли органами власти, каковые всегда шли мне навстречу. В моем распоряжении всегда имелись готовые бланки пропусков и всякого рода удостоверения за надлежашчими подписями и печатью для пропуска через границу в Монголию или Совроссию, что исключало всякую возможность предательства со стороны канцелярских служащих, ведающих выдачей пропусков. Положительно никто не знал, кроме меня, кто и куда проезжал и по каким делам. Всего мной было переотправлено более 50 человек работников, причем все они были снабжены литературой, оружием и соответствующими инструкциями. Создавшаяся связь с Увоенкомом в Желтуре m. Ивановым создала возможность обоюдной информацчии. В этом последнем районе нашли себе приют не только отдельные лица и группы белогвардейцев, но там под негласным покровительством бродили целые отряды белогвардейцев. Сущзественно важным было знать все их передвижения и намерения. В этой информации главную роль играли те монголь, с которыми я так близко сошелся и которые в скором времени убедились, что я к ним искренне отношусь. Обоюдными усилиями мне удалось привлечь на свою сторону монгольского влиятельного князя Сумья-Бейсе, каковой перешел на русскую территорию со всем своим хошуном. После перехода этого князя на сторону Совроссии дело организации монгольского отряда значительно продвинулось вперед. Этот же переход в значительной степени облегчил информацию, ибо сами монголь значительно легче получают необходимые нам сведения. Я всегда своевременно знал о всех передвижениях китвойск, также белогвардейских банд, что давало возможность своевременно принимать соответствуюшие меры.

С прибытием председателя монтиботдела работа НРП значительно оживилась. При его участии мне удалось созвать несколько совещзаний НРП, на которой определялись ближайтие задачи партии по работе в Монголии. Цельий ряд важных вопросов были подвергнуты рассмотрению, в результате которых были приняты решения, каковые в дальнейшем проводились в жизнь, сообразуясь с возможностью. Обсуждались, например, такие вопросы как привлечение монгол в партию в широком масштабе, об организации тесного контакта с разбросанныли по необъятной Монголии членами партии, затем об организации реальной силь, на которую 
НРП могла бы опереться в нужную минуту. Всего было проведено четыре совещания, причем последние два совещуания уже происходили тогда, когда был организован военный итаб НРП, и проходили при участии представителей от штаба. Конечно, все совещуания проходили при непосредственном участии Уполнаркоминдел, а последнее и под его председательством. Это последнее заседание носило скорее военный характер, на котором главное место было уделено военным действиям, каковые предполагались в ближайшем будущем. Необходимо было выработать план организации отрядов, снабжения их оружием, также необходимо было рассмотреть и ту тактику, каковой следовало держаться при занятии Маймачена. Подвергнут был [рассмотрению] также вопрос обсуждения о взаимоотношениях китайских властей и НРП. Выяснилось на совещуании, что китвласти стремятся войти в соглашение с НРП о добровольном прекрашении военных действий. Обсуждался также вопрос о посылке ультиматума китвластям о добровольном разоружении и сдачи власти НРП, но этот вопрос совещуанием оставлен открытылым.

Здесь следует отметить, что вопрос о занятии Маймачена обсуждался и раньше, а именно 12 февраля состоялось совешание с присутствием Начгара m. Катерухина. На этом совещуании определилась полная возможность занять Маймачен силами самих монгол. Постановлено было организовать отряд из монголов в 300 человек, каковой был бы достаточно велик, овладеть Маймаченом и разоружить находящчиеся там китчасти. План этот в то время мог бы вполне привести к желательному результату, так что в то время китвойск в Маймачене почти не было, а отступающие войска из Урги находились на значительном расстоянии от Маймачена. Но когда отряд был уже сорганизован и готов приступить к действиям, начгар Катерухин отказался выдать обещуанное им оружие и отряд был распущен. На всех собраниях-совещзаних НРП Уполнаркоминдел по вопросам участия Совроссии и ДВР в активных действиях против китвойск совместно с монголами проводил ту мысль (линию), что необходима величайшая осторожность в деле организации совместных военных действий.
Важнейшая оплошность в этом направлении может создать крайне нежелательные последствия международного характера. Так, например, на заседании МРП с представителями итаба по вопросу об ультиматуме китвластям о разоружении и передачи власти МРП, - Уполнаркоминдел внес определенное положение не вести с китчиновниками никаких переговоров, не предъявлять никаких ультиматумов, полагая, что такое могут дать только отрицательные результатьл. Упонаркоминдел также настаивал на том, что в настоящее время необходимо всячески увеличивать свои реальные силь и немедленно приступить к активным действиям - разоружить набегами отдельные части китсолдат, давая им чувствовать организованную силу МРП. Уполнаркоминделу ясно выявлялось, что китвласти усмотрят в ультиматуме поддержку Совроссии, на которую опирается МРП. Кроме того, Уполнаркоминделу представлялось гибельным всякая проволочка, каковая без сомнения вытекает из ведения переговоров. Создавшееся положение в Урге дает возможность Унгерну приобретать исключительное влияние на Монголию, что возможно может привести к соглашению с Китаем и ориентации на Японию в ущуерб нарождающемуся национально-революиионному движению с ориентацией на Совет Россию. Таким образом, время при данном положении имеет огромное значение. Это обстоятельство и побуждало Уполнаркоминдел - на всех совещуаниях настаивать на немедленной организации монгольского партизанского движения под руководством МРП и непосредственном участии живых сил Совет. России и ДВР. В настоящуее время это последнее пожелание Уполнаркоминдела реализуется. Уже отряды монгол сорганизованы и действуют. Точно также по инициативе Уполнаркоминдел в монгольские отряды включены военные инструкторы, каковые были взяты из армии ДВР при его посредстве. Трудно, конечно, учесть всю работу в области организацчии - слишком разнообразной она была по своей сущнности, быстро менялась по своей форме в зависимости от ичелого ряда событий, одно за другим.

Дипломатическая работа: Как-то странно звучит слово «дипломатия» в устах коммуниста. Тем не менее, как наше- 
му Наркоминдел, так и нашим окраинным представителям вопреки своим внутренним убеждениям приходится обращаться $\kappa$ этой старой плутовской работе в своих сношениях со своими буржуазными соседями. Уже те препятствия, каковые правительство Пекинское поставило мне в попытке проехать в Ургу, свидетельствуют о том, что оно не только не хотело признавать правительства Совет. России, но даже и не хотело подавать повода и думать, что оно имеет хотя бы отдаленное прикосновение со страной коммунистов. При таких обстоятельствах надежды на изменения отношения Пекина к застрявшему Уполнаркоминдел в Троицкосавске были весьма плохие. Тем не менее, не прошло и 8 месяцев, как те же власти в лице наместника Монголии Чэн-И и других правителей должны были силой обстоятельств в корне изменить свое отночение и уже не только $\kappa$ Уполнаркоминдел, но и иельмм рядом своих официальных обращчений фактически признали Совет. Россию.

Переговоры с китайскими властями начинаются в прошлом сентябре по вопросам, связанным с убытками населения китвластями Центросоюзу. Всего было послано четыре протеста против насилия, грабежей и убийств над служашими Центросоюза, чинимым китсолдатами. Приблизительно к этому же времени относятся и протесты того покровительства, каковое китвласти оказывали белогвардейским бандам и контрреволючионерам в Монголии. В это время китайские пограничные чиновники почти открыто действовали с белогвардейцами и не только ничем с их стороны не было принято для противодействия этим белогвардейским организациям, но они даже не сочли для себя необходимым мне ответить на все посланные запросы и протесты. И только уже после первых столкновений с Унгерном, когда почувствовалась шаткость китайского положения $в$ Монголии, китайиы видимо поняли, что им с Унгерном не по дороге и начали быть более сговорчивыми. 3-го декабря впервые ко мне явился чиновник НЮВИНБИН и с притворством свойственным только китайизам выразил удивление при встрече и заявил, что им не было известно, что Уполнаркоминдел все ещче находится в Троицкосавске. Явился Нювинбин с устным протестом против ввода войск Совроссии в Джкицнский район. 13-го декабря тот же Нювинбин явился вторично с протестом, только на этот раз письменным, но исходящчим не от сановника Лупантао, а от Нювинбина. 15-го декабря впервые получается от китвластей офичиальное сообщение о том, что чех Вебс является самозванием и не уполномочен Китайским Правительством как его представитель. Так постепенно китвласти стали обрашиаться к Уполнаркоминдел как представителю Совет. России, в первое время пугливо, опасаясь своими действиями признать правительство, непризнанное Антантой. После же падения Урги, когда выяснилось тяжелое положение отступающих солдат, когда определенно выяснились все результаты их репрессивной политики по отношению к Монголии, когда они почувствовали себя в стране врагов, тогда окончательно они не только готовы были признать Советское Правительство, но и открытоо обратились за помощзью к этому непризнанному ими правительству. Совместными действиями пограничных властей ДВР и Уполнаркоминдел в результате каковых бегушим китчиновникам были закрыты все пути через территорию ДВР и открыта была лишь одна дорога по реке Селенге. Это обстоятельство заставило всех без исключения уезжающих китайцеев обраматься за визами к Уполнаркоминдел. Не имея возможности проехать в В-Удинск кроме указанного пути, китвласти стали обраштаться офичиально к Уполнаркоминделу за визами. В течение небольшого промежутка времени было визировано несколько тысяч китайских паспортов. Больиинство являлись либо беженцами из Урги, либо купечество из Маймачена. Уехало также значительное количество чиновников всех ведомств. При своем отъезде значительное количество солидных китайских фирм офицчиальныли обращчениями Уполнаркоминдел просили взять их жизнь, как и их имущество под покровительство Совет. России. Таких обрашений к Уполнаркоминдел было сделано около сорока. В некоторых обращениях от фирм и государственных учреждений указывается, что китвласти бегут и оставляют на произвол судьбы, а потому они обращаются к Совет. России с просьбой взять под свое покровительство. Есть и такие заявления, где говорится, что зна- 
менитый хитрый чиновник Нювибин всегда противодействовал именно таможенным чиновникам, а потому они обращуаются за покровительством к Советской России, а не к своим властям. Несколько позже китвласти в лище Наместника Урги, Улясутая, Кобдо и Урянхая обрашуаются к Уполнаркоминдел с официальной просьбой снабдить их оружием и патронами, и снарядами. Таких обращений было два, причем в одном из указанных обращений китвласти просят вылдать им шесть пушек.

15-го февраля от наместника Чэн-И поступило официальное заявление выдать ему визу для проезда в Пекин для личного доклада. Воспользовавшись желанием Чэн-И уехать от назревавших событий, Уполнаркоминдел предложил ему выяснить ряд вопросов в связи с появившимися в ряде районов разбойничьих банд как китайских, так и белогвардейских, каковые занимались грабежом местного населения. На состоявшемся совещании Наместника Чэн-И с Уполнаркоминдел китвласти выразили желание предоставить Совет. России ввести свои войска в 25 верстную зону для ликвидации указанных разбойничьих банд. Впоследствии это согласие на ввод войск в 25 верстную зону [было получено] в официальной письменной форме. Между тем атмосфера сгущуалась. Прибывавшие китсолдаты, измученные тяжельм переходом в зимнее время из Урги до Маймачена, голодные, косвенно выражали свое желание расправиться с властелинами Монголии. Их они считали главными виновниками Ургинской катастрофы. Создалась, таким образом, необходимость для китвластей немедленно убраться подальше от своей же собственной армии. Между тем Уполнаркоминдел медлил с визами, так как, по его мнению, перед отъездом администрации необходимо было решить вопросы, сущуественно важные для Совет. России. Необходимо было выяснить вопрос, кто же будет ликвидировать оперировавшие белогвардейские банды в п пределах Монголии. Если китвласти вследствие создавшихся обстоятельств не в состоянии справиться с разбойными бандами, то, следовательно, для защчтты свочх интересов в Монголии, а также для обеспечения мира в своей пограничной полосе Совет. Россия должна принять самые энергичные меры [против] всех враждеб- ных группировок в пределах Монголии. Но в силу международного положения Уполнаркоминдел считает необходимым войти в соглашение с китвластями для того, чтобы обеспечить Совет России свободу действий не только в 25 верстной полосе, но вообще во всей Внешней Монголии. Для этого, чтобы избежать личной ответственности, Наместник Чен-И 22-го февраля передает все свои полномочия Наместника Монголии сановнику Лию-Ань, причем о передаче своих полномочий Наместник Чен-И официально уведомил Уполнаркоминдел.

3-го марта уже новый Наместник Лию-Ань в официальном заявлении, изложив вкратце историю занятия Урги Унгерном, обрашается к Совет. России в лице ее представителя Уполнаркоминдел за помощьью против вторгнувшихся в предель Монголии унгерновских банд, причем на этот раз новый Наместник Монголии не ограничивается 25 верстной полосой, а представляет Совет. России полное право ввода войск на всю Внешнюю Монголию, представляя свободу действий, оговаривая, однако, что Россия, [будучи] дружественной страной по отношению к Китаю, конечно, выведет свои войска из пределов Монголии по ликвидаџии унгерновского движения. Так, шаг за шагом, китвласти, вершившие дела и судьбу Монголии, презрительно относившиеся к Совет. России, принуждены были ходом собылтий не только признать Советское Правительство, но и обрашаться к нему за помощьюю в критическое время. Конечно, это признание не является признанием всего правительства Китая, тем не менее, оно является характерным для переживаемого нами времени и неуклонно ведет к заключению, что время не за горами, когда и иентральное китайское правительство в силу давления даже чисто экономических должно будет сделать запретный шаг.

Политическая работа: поставленная мне задача Сибмиссии пробраться в Ургу, центр всей культурной жизни Монголии, для осуществления определенных целей, обязывало меня быть крайне осторожным, чтобы не дать повода китвластям приобщуить меня к коммунистической партии и таким обосновать свое нежелание пропустить меня в Ургу моей политической окраской. Это обстоятельство лишало меня возможности примкнуть к местной орга- 
низаччи и принимать какое-либо участие в ее работе в первый период моего пребьвания в Троицкосавске. Разносторонность моей работь, хотя и не оставляла времени для чисто политической деятельности, тем не менее постоянная острая нужда в активных политических работниках обязывала все же принимать посильное участие. Но войти в организацию мне пришлось уже гораздо позже, после того как у меня не осталось никакой надежды поехать в Ургу. Правда, что вошедши в организацию местной коммунистической партии и будучи избран в члены комитета, я был фактически комитету мало полезен, так как мне пришлось принимать участие лишь в пленарных заседаниях. Однако все крупные начинания комитета партии не обходились без моего участия и содействия. Касалось ли то вопроса «Недели фронта» или «Недели ребенка», мне, часто обремененному до крайности, приходилось брать на себя, то те, то другие поручения. Мое положение в городе давало мне возможность, например, собрать самую крупную сумму денег для организации «Недели Ребенка» и т. д. Следует также отметить, что мне приходилось принимать участие в партсудах, а также выступать с речами всякий раз, когда приходилось сталкиваться с представителями монгольской организации, излагать перед ними политику правительства Совет. России в монгольском вопросе и инструктировать их по всем вопросам непосредственно касаюшихся их деятельности.

Состоявшаяся уездная партконференция 5-го марта вновь избрала меня членом парткома, зная определенно, что я могу уделять организации лишь незначительное время. Однако самим существованием в моей деятельности в комитете являлась та исчерпьвающая информачия, каковая мной систематически доставлялась комитету, что, конечно, было крайне ценно и давало полную возможность ориентации.

Экономическая работа: Одновременно с работой по представительству Совет. России Комиссар Иркутского Губпродкома поручил мне фактический контроль над всей деятельностью Центросоюза. Я ясно отдавал себе отчет, насколько тяжела и ответственна та работа, каковая, в сущности, определяется фактическим контролем. В особенности тяжелой она являлась в самом начале моего пребывания в Троицкосавске, когда Центросоюз, повинуясь своим старым порядкам, действовал, конечно, не в интересах государства. Наличие большого количества служаших, почти открыто относившихся враждебно к Советской власти, начинавшей в то время превращать эту организацию частного характера $в$ государственную. Были и такие служашие в Центросоюзе, каковые, пользуясь своим влиянием и средствами, почти открыто содействовали контрреволюиии, снабжая ее всеми возможными средствами. Мне ясно представлялась необходимость сохранения всего налаженного аппарата Центросоюза, вместе с тем, с первого же знакомства со всей этой довольно сложной экономической организацией определилась необходимость ее очищения от вредных элементов и направления всей ее деятельности в желательную для нас сторону.

Считая все же эту работу как бы побочной, я откладывал знакомство с сущностью деятельности Центросоюза до налажсивания моей основной работы. Но вопреки моим первоначальным желаниям мне пришлось взяться за работу по фактическому контролю за деятельностью Центросоюза гораздо раньше. В начале сентября произошло ограбление Центросоюза на 21.000.000 [рублей (?) в результате нападения на] следовавших в Ургу. Характер ограбления ясно указывал, что в нем должны были принимать участие сами служашчие Центросоюза. 5-го сентября мне было поручено расследование этого ограбления вместе с приезжающей из Иркутска комиссией и в связи с этим расследованием мне пришлось познакомиться со всей работой этой автономной организации в частности в Маймачене.

Первыли моими мерами определялся контроль над вывозом в Монголию ценностей, также пропуском служаших. Следует отметить, что для заготовок мяса РСФСР отпущено Центросоюзу 1100 пудов слитков серебра, каковое целиком должно было поступить в мой адрес для планомерного распределения закупочным отрядам, оперировавшим в Монголии. Вся ответственность за указанные цуенности падала на меня. Затем пограничные власти пропускали все ценности Центросоюза только за моей подписью. 
Не следует также забывать, что моя деятельность в связи с Центросоюзом протекала при крайне тяжелом гонении китайских властей на эту организацию. Они скоро поняли, что Центросоюз лишь прикрывается вывеской Центросоюза, а фактически он является организачией Совет. России, и где только могли, ущемляли ее работу. Очень часто без всяких поводов запрещали прогон через гранииу уже закупленный скот, и приходилось прогонять его нелегальными способами. Затем начались массовые реквизиции и фуража, и орудий, а вскоре поход был общий против организаиии в иелом. Начались грабежи и убийства служащих в различных пунктах Монголии. Ни на один из моих протестов, как уже известно, китвласти не ответили. И только уже впоследствии, когда власть их пошатнулась, когда они нам кое-что вернули из реквизированных сельскохозяйственных орудий, как грабли и сенокосилки, а также автомобиль.

Не малое внимание приходилось уделять пропускам служсащих Центросоюза в Монголию, а также Совроссию. Мне было хоромо известно, что у них имеется связь с белогвардейцами и их организациями и что они пользуются правом пропусков для активной их поддержки. Приходилось очень часто накладывать свое «вето» на многие пропуска, полученные служащиии Центросоюза.

После падения Урги, когда выяснилась возможность продвижения унгерновщев $и$ монгол в сторону Маймачена, Центрсоюз при моем непосредственном участии использовал создавшееся положение и скупил значительное количество товаров при значительно пониженных ценах. В общем, товаров было закуплено на 130.000 долларов, причем при приблизительном подсчете Центросоюзу является чистой прибыли для государства минимум 300.000 долларов. Значительное количество иенностей и товаров китайцев взято с моей санкиией Центросоюзом на хранение.

ЗАКЛЮЧЕНИЕ. Настоящий мой доклад имеет характер схемь, но нет решительно никакой возможности объять в деталях всю ту занятость, каковая изо дня в день протекала при очень тяжелых условиях. Не следует забывать, что у меня почти всегда отсутствовало млн средства, приходилось почти все время их изыскивать, занимая то здесь, то там. Трудно, конечно, было вообще работать при полном отсутствии сотрудников, лишь изредка удавалось иногда пользоваться случайными услугами для иеелей перевода и информации. Абсолютно вся канцелярская работа ложилась всечело на меня, и только мой долгий опыт как бухгалтера и каниеляриста дал мне возможность справиться относительно удовлетворительно с этой технической работой.

В особенности тяжело было в первое время, когда отсутствовала моя семья, приходилось не только быть канщеляристом, машинистом, но и исполнять свои домашние нужды.

И если ко всему сказанному прибавить еше мое крайне расстроенное здоровье, выражаюшиеся в хроническом катаре всего кишечно-желудочного тракта (наследство каторги), то станет ясно, что больше, чем мною достигнуто, не представляется возможным.

$$
\begin{aligned}
& \text { Город Троиикосавск } \\
& 18 \text { Марта } 19212 . \\
& \text { С товарищеским приветом } \\
& \text { (подпись) }
\end{aligned}
$$

Как мы видим, «Отчет О. И. Макстенека с 1 июня 1920 г. по март 1921 г.» является ценным архивным документом, проливающим свет на предысторию и историю Монгольской революции 1921 г. Во введении к отчету О. И. Макстенек четко указывает, что ситуация, складывавшаяся в Монголии, могла быть успешно решена только с включением ее в орбиту хозяйственной жизни на Дальнем Востоке. Монголия к тому времени развивалась в русле транснациональной истории. На ее территории находились российские и китайские торговые компании, китайские войска. Шел беспрерывный и быстро меняющий суть и направление поток идей и ресурсов, приведший в итоге к окончательному созреванию монгольского национального движения и к дальнейшей борьбе за обретение независимости страны. Отчет О. И. Макстенека уникален тем, что это взгляд не стороннего наблюдателя, а непосредственного участника и организатора революционных событий в Монголии.

Отчет О. И. Макстенека позволяет оценить весь объем и охват его разносторонней деятельности. Очевидно, именно при нем 
в Троицкосавске было налажено постоянное телеграфное информирование вышестоящих органов власти ДВР и РСФСР о ситуации в Монголии и в российско-монгольском приграничье. О. И. Макстенеком были также произведены фотосъемки топографических и военных карт. Как явствует из отчета, именно он явился ключевой фигурой - организатором встреч трех групп монгольских делегатов от МНП, тайно перебравшихся в ДВР. В его задачи входило снабжение монгольских революционеров документами (пропусками) и конспиративными квартирами, инструктаж и отправка в Верхнеудинск.

\section{Заключение}

Таким образом, Отто Иванович Макстенек, наряду со знаменитой монгольской семеркой (С. Данзан, Х. Чойбалсан, Д. Бодоо, Д. Чагдаржав, Д. Сухэ-Батор, Д. Догсом и Д. Лосол), а также российскими партийными функционерами, коминтерновцами и дипломатами, среди которых особенно выделяются имена Б. З. Шумяцкого и Э.-Д. Ринчино, сыграл значительную роль в подготовке и осуществлении Монгольской революции. Не случайно он в числе первых, наряду с Б. 3. Шумяцким, был награжден монгольским орденом Красного Знамени. Между тем, в российской историографии особая роль российского дипломата в подготовке революции в Монголии не получи-

\section{Источники}

Архив МИД Монголии - Архив Министерства иностранных дел Монголии.

ГА РФ - Государственный архив Российской Федерации.

Мартиролог - Мартиролог жертв политических репрессий, расстрелянных и захороненных в Москве и Московской области в 1918-1953 гг. // URL: https://www.sakharovcenter.ru/asfcd/ martirolog/ $\mathrm{id}=10371 \& \mathrm{t}=$ page (дата обращения: 01.12.2019)

Российско-монгольское 2019а — Российско-монгольское военное сотрудничество (1911-1946). Сборник документов. Ч. I / И. И. Кудрявцев, Б. В. Базаров. М.: Изд. дом «Граница», 2019. 360 с.

Российско-монгольское 20196 - Российско-монгольское военное сотрудничество (1911-1946). Сборник документов. Ч. II / И. И. Кудрявцев, Б. В. Базаров. М.: Изд. дом «Граница», 2019. 328 с. ла должной оценки. Достаточно отметить, что его имя отсутствует и в справочниках, и в энциклопедиях по истории Октябрьской революции, Гражданской войны. Нет его и в трехтомном дипломатическом словаре под редакцией Министра иностранных дел СССР А. А. Громыко. А портретная галерея полномочных представителей Советской России / СССР / Российской Федерации в посольстве России в Монголии открывается портретом полномочного представителя РСФСР Николая Марковича Любарского (срок полномочий 7 июля 1922 - июль 1923 гг.).

Как показывают представленные архивные документы, уполномоченный НКИД в Монголии О. И. Макстенек из-за противодействия китайских властей был вынужден остановиться на длительное время в Троицкосавске. Тем не менее, несмотря на тяжелые условия работы, он сумел создать необходимые условия для монгольских революционеров. В целом, можно констатировать, что в июне 1920 - марте 1921 гг. О. И. Макстенек провел большую работу в деле подготовки Монгольской революции 1921 г. Его помощь, по сути, охватывала все сферы деятельности монгольских делегатов. Он помог им без затруднений добраться из Троицкосавска в другие города ДВР и Советской России, а впоследствии организовать в Троицкосавске собрания монгольских революционеров и первый съезд МНРП.

Жабаева 2001 - Жабаева Л. Б. Э.-Д. Ринчино и формирование государственности монгольских народов в первой четверти XX в.: автореф. дисс. ... д-ра ист. наук. Улан-Удэ, 2001. 39 c.

Казанин 2009 - Казанин М. И. Избранное. М.: Памятники исторической мысли, 2009. 431 с. Курас 2016а - Курас Л. В. Место и роль Иркутска в осуществлении политики Коминтерна // Известия Иркутского государственного университета. Серия История. 2016. Т. 16. C. 173-182.

Курас $2016 б-$ - Курас Л. В. Транснациональная история монгольского мира в условиях революционного подъема: первая четверть XX в. Иркутск: Оттиск, 2016. 252 с.

Курас 2017 - Курас Л. В. Панмонголизм как проявление этничности монгольского мира в первой четверти XX века. Иркутск: Оттиск, 2017. 188 с. 
Курас, Цыбенов 2020 - Курас Л. В., Цыбенов Б. Д. Отто Иванович Макстенек: год из жизни советского дипломата // Известия Иркутского государственного университета. Серия История. 2020. Т. 32. С. 83-90.

Хишигт 2011 - Хишигт Н. Монголын хувьсгал: 1921 (Монголын үндэсний ардчилсан хувьсгалын түүхийг нэхэн судлахуй) (= Монгольская революция: 1921 г. (Исследование истории Монгольской националь-

\section{Sources}

[Russian-Mongolian Military Cooperation: 19111946]. Coll. documents. Vol. I. Kudryavtsev I. I., Bazarov B. V. Moscow: Granitsa, 2019. 360 p. (In Russ.)

[Russian-Mongolian Military Cooperation: 19111946]. Coll. documents. Vol. II. Kudryavtsev I. I., Bazarov B. V. Moscow: Granitsa, 2019. 328 p. (In Russ.)

[Victims of Political Repressions Executed and Buried in Moscow and Moscow Oblast, 19181953: Martyrology]. Available at: https:// www.sakharov-center.ru/asfed/ martirolog/ ? $\mathrm{id}=10371 \& \mathrm{t}=$ page (accessed: 01.12.2019). (In Russ.)

Ministry of Foreign Affairs of Mongolia, Archives.

State Archive of the Russian Federation.

\section{References}

Choybalsan Kh., Losol D., Demid G. [Emergence of the Mongolian People's Revolution: a Brief History]. Ulaanbaatar: People's Publ. House, 1979. 310 p. (In Mong.)

Kazanin M. I. [Selected Works]. Moscow: Pamyatniki Istoricheskoy Mysli, 2009. 431 p. но-демократической революции)). Улаанбаатар: Бэмби Сан, 2011. 299 с.

Чойбалсан, Лосол, Демид 1979 - Чойбалсан Х., Лосол Д., Демид Г. Монгол ардын ундэсний хувьсгалын анх уусэж байгуулагдсан товч туух (Хоердахь удаагийн хэвлэл) (= Краткая история возникновения национальной революции монгольского народа). Улаанбаатар: Улсын хэвлэлийн газар, 1979. $310 \mathrm{x}$.

(In Russ.)

Khishigt N. [Mongolian Revolution of 1921: a Study of the Mongolian National Democratic Revolution]. Ulaanbaatar: Bembi San, 2011. 299 p. (In Mong.)

Kuras L. V. [Panmongolism as a Manifest of the Mongolian World's Identity: 1900s - 1920s]. Irkutsk: Ottisk, 2017. 188 p. (In Russ.)

Kuras L. V. [Transnational History of the Mongolian World in a Revolutionary Upsurge: 1900s 1920s]. Irkutsk: Ottisk, 2016. 252 p. (In Russ.)

Kuras L. V. The place and role of Irkutsk in the implementation of the Far Eastern policy of the Comintern. The Bulletin of Irkutsk State University. Series 'History'. 2016. Vol. 16. Pp. 173-182. (In Russ.)

Kuras L. V., Tsybenov B. D. Otto Ivanovich Makstenek: year from life of the Soviet diplomat. The Bulletin of Irkutsk State University. Series 'History'. 2020. Vol. 32. Pp. 83-90. (In Russ.)

Zhabaeva L. B. [E.-D. Rinchino and the Shaping of Mongolian Nationhoods: 1900s - 1920s]. Dr. Sc. (history) thesis abstract. Ulan-Ude, 2001. 39 p. (In Russ.) 